\title{
DA TORTUOSA ELUCIDAÇÃO DO TRÁGICO: A AGÊNCIA DA NOÇÃO DE BULLYING EM MEIO A EVENTOS EXTREMOS DE VIOLÊNCIA JUVENIL
}

\author{
Juliane Bazzo $^{1}$
}

\author{
Um caso emblemático \\ Deu-se nos Estados Unidos: \\ Em 99, um momento trágico; \\ Os países lamentam o ocorrido. \\ No colégio Columbine \\ High School, Colorado, \\ Dois jovens com carabina: \\ Doze alunos foram imolados. \\ Umas vinte foram feridas \\ Naquele dia sangrento; \\ Faziam preces pela vida \\ Todos deitados ao relento. \\ Gonçalo José Soares de Macedo, Bullying em cordel
}

As vivências enquanto estudante no Ceará e depois como porteiro de um colégio particular na cidade de São Paulo inspiraram Gonçalo José Soares de Macedo a lançar mão da arte de rimar para conceber o livro "Bullying em cordel”. Além disso, conforme contou em entrevista à imprensa, Macedo teve sua criatividade mobilizada uma vez impressionado por duas tragédias juvenis conectadas à questão do bullying: os ataques armados em Columbine High School (Colorado, Estados Unidos) e na Escola Municipal Tasso da Silveira (Realengo, Rio de Janeiro - RJ), ocorridos respectivamente em 1999 e 2011, ambos com vítimas fatais (Piza, 2017).

Hoje, seguramente se pode dizer que essa associação entre bullying e episódios de violência juvenil extrema se encontra incrustrada no imaginário coletivo não apenas brasileiro, mas ocidental. Este artigo propõe-se a explorar os meandros de tal vínculo a partir de um viés antropológico e, portanto, lança mão da etnografia como elemento primordial. Trata-se de uma trilha de abordagem que não se concentra no "horror" estatístico desses acontecimentos, algo já feito ad nauseam pela imprensa de massa. Sob uma luz diferenciada, ocorrências como os ataques armados outrora citados são posicionados enquanto “eventos críticos”, conforme a acepção de Veena Das (2007).

\footnotetext{
${ }^{1}$ Universidade Federal do Rio Grande do Sul, Brasil.
} 
Segundo essa antropóloga, os "eventos críticos" não constituem situações incomuns fechadas em si mesmas, mas sim episódios que encontram raízes na sociabilidade cotidiana e que, uma vez concretizados, continuam a introduzir suas ramificações na vida diária. Essa ótica retira tais episódios extremos de uma posição atomizada irreal, comumente explorada pela leitura midiática sensacionalista, para tratar do "trabalho do tempo" sobre eles, não só em uma direção pretérita, mas também futura. Nessa lógica, é possível dar-se conta que o ordinário e o extraordinário, a despeito de instâncias diferenciadas, articulam-se sucessivamente, num ciclo ininterrupto de impactos que ultrapassam as fronteiras da localidade $(i d$.$) .$

A análise aqui apresentada integra uma investigação mais ampla, constituída por minha tese de doutorado em antropologia social, cuja pesquisa concentrada no Estado do Rio Grande do Sul objetiva problematizar os agenciamentos que a noção de bullying tem ganhado no cenário brasileiro contemporâneo. O conceito de "agência" que utilizo é aquele cunhado por Sherry Ortner (2007), para quem quaisquer atores são dotados da capacidade de agenciar, porém, em graus diferenciados e imprevisíveis, condicionados à natureza das relações de poder vigentes em cada contexto socio-histórico.

Bullying designa em língua inglesa o ato decorrente do substantivo bully, que significa algo próximo a "brigão" ou "valentão" em português. De autoria atribuída ao sueco Dan Olweus (2006), professor e pesquisador do campo da psicologia na Universidade de Bergen, na Noruega, o bullying é um construto científico da década de 70, que vem se alastrando mundialmente desde então, na função de nomear agressões de natureza intimidante e repetitiva entre pares nos ambientes escolares. Pioneiramente, Olweus situou a identificação, o combate e a prevenção desse tipo de comportamento como uma questão de direitos humanos fundamentais nas modernas democracias.

No Brasil, o termo cunhado por Olweus experimenta uma vultosa popularização somente ao longo dos anos 2000. A essa altura, já havia transcendido, aqui e internacionalmente, a aplicação ao universo educacional. Seu mais famoso desdobramento reside no chamado cyberbullying, que consiste, grosso modo, no bullying praticado via meios eletrônicos. Porém, outras facetas, captadas ao longo do exercício etnográfico, vêm se destacando, dentre elas, o bullying étnico-racial, o bullying homofóbico e o bullying corporativo. Nesse panorama, compreendo o bullying no sentido determinado por Michel Foucault (1984), como um "dispositivo" que a um 
só tempo opera como um saber científico, uma técnica de governo e um mecanismo gerador de novas subjetividades.

Por intermédio dessa moldura, minha investigação de doutoramento atenta para a atuação dos "empreendedores morais" (Becker, 2008): indivíduos, instituições, iniciativas e documentos responsáveis hoje por agenciar a noção de bullying numa variedade de contextos em nosso país e, dessa maneira, alavancar uma série de filosofias, políticas e práticas, orientadas para fins diversificados. Por essa via, na esteira do que faz Ian Hacking (2013) para o "abuso infantil", a tese preocupa-se em discutir como o conceito de bullying aparece moralmente "moldado" por diferentes agentes, que conferem a ele roupagens diferenciadas a depender da sua "rede de interesses".

Dessa forma, a exemplo da reflexão realizada por Didier Fassin e Richard Rechtman (2009) acerca do alastramento da noção de "trauma" na contemporaneidade ocidental, meu estudo quer demarcar a "economia moral" em meio à qual o conceito de bullying desponta no contexto brasileiro. Sob tal lógica, o bullying perfaz mais que um construto científico a nomear comportamentos que, indubitavelmente, não são uma novidade nos meios educacionais. Trata-se de uma categoria a comunicar sensibilidades específicas sobre violência, sofrimento e reparação hoje existentes em nosso país, como parte do lado ocidental do mundo. Logo, traz consigo um novo vocabulário, desencadeador de "efeitos performativos" sobre a realidade. Esses impactos têm ultrapassado os propósitos acadêmicos pensados para o termo e revelado a "inteligência social dos atores", a explorar no dia a dia a "dimensão tática" do construto.

A etnografia desenvolvida possui uma característica "multilocalizada" (Hannerz, 2003), a qual pressupõe a inserção do antropólogo em "esferas de valor distintas" (Cardoso de Oliveira, 1994), nesse caso, com a finalidade de pensar sobre moralidades a gravitar em torno de "manifestações empíricas" do agenciamento da noção de bullying no cenário brasileiro. A investida em diferentes instâncias de pesquisa se sustenta na premissa de que entre elas há “conexões" (Strathern, 2014), de ordem holográfica e complexa, capazes de se tornarem visíveis e de serem problematizadas etnograficamente.

Desse modo, entre os anos de 2014 e 2015, o trabalho de campo construiu-se a partir da imersão cotidiana em duas escolas, uma pública e outra privada, situadas na região dos municípios de Gramado e Canela, na Serra Gaúcha, onde à época eu residia. Ademais, contemplou a investigação em órgãos públicos, redes científicas e 
movimentos sociais especialmente na capital Porto Alegre (RS), como também o monitoramento de conteúdos midiáticos, de produtos de mercado e de documentos de referência, tanto nacionais quanto internacionais, em que o bullying emerge como mote.

O presente artigo, entretanto, coloca em primeiro plano uma fase subsequente da empreitada de campo, levada a cabo entre 2016 e 2017. De um lado, essa etapa incluiu o acompanhamento in loco de mobilizações da Associação Anjos de Realengo, criada por familiares e amigos das vítimas do ataque armado à Escola Municipal Tasso da Silveira, no referido bairro carioca em 2011. De saída, importa mencionar que essa entidade cuja atuação venho acompanhando na mídia e em redes sociais desde os primórdios da feitura da tese - tem conferido uma agência singular à noção de bullying, isso no interior de um trabalho implementando em prol da memória dos jovens falecidos e pela segurança nas escolas.

De outro lado, tal etapa abarcou o estágio doutoral que realizei por nove meses nos Estados Unidos onde, desde a cidade de Nova York, pude entrar em contato com uma atmosfera na qual se insere uma gama de políticas e programas antibullying, capitaneados por agentes públicos, por grupos acadêmicos e por organizações da sociedade civil $^{2}$. Tal oportunidade de conhecimento in situ demonstrou-me com claridade que tanto a maneira de operar dessas iniciativas, quanto a percepção pública geral sobre o bullying, encontram na tragédia em Columbine High School um divisor de águas sem precedentes históricos no quadro estadunidense.

Dessa forma, com base especialmente nos dados coletados nessa etapa mais recente do trabalho de campo, quer-se destrinchar nesse artigo de que maneiras sujeitos, instituições, iniciativas e documentos implicados nessas situações de violência extremada vêm se construindo eticamente antes, durante e depois desses episódios. Ou seja, como estão estabelecendo fronteiras morais entre o bom e o mal, o certo e o errado, o direito e o dever. Nesse processo, o bullying desponta como um suporte ímpar para comunicar duas mensagens prioritárias e conflitantes, como adiante se discutirá.

Em uma frente, aparece como conceito a atribuir uma elucidação acabada para tais tragédias; em outra, como uma ideia a contribuir para a politização da violência extrema e, portanto, para manter acesa a denúncia dela na esfera pública. Logo, numa ponta, o bullying é abraçado como explicação para a morte; na outra, o construto aparece agenciado em prol da manutenção da memória e do curso da vida, depois do

\footnotetext{
${ }^{2} \mathrm{O}$ período de estudos no exterior foi realizado sob auspícios de bolsa de estudos proveniente do convênio Capes/Fulbright.
} 
arrebatamento pelo trágico. Tal contraste desvela uma distinção e, sobretudo, uma tensão permanente entre a "violência vivida" e a "violência representada" (Vigarello, 1998) na trajetória que cruza eventos extraordinários e o construto do bullying no Ocidente contemporâneo.

\section{Noruega, 1982}

De origem sueca, mas com trajetória acadêmica construída na Noruega, o psicólogo Dan Olweus (2013) encontrou nos idiomas desses países as primeiras palavras para denominar rudimentarmente, no início da década de 70, aquilo que adiante ele definiria cientificamente como bullying. O termo mobbning em sueco - em norueguês, mobbing - foi emprestado da literatura da Etologia. Nesse campo, remete ao ataque agressivo perpetrado por um coletivo - de animais e, por extensão, de pessoas contra um Outro, quer seja um espécime diferenciado, quer seja um indivíduo desviante dos padrões grupais. À época, no mundo anglófono, a raiz mob configurava um vocábulo completo já explorado pela psicologia social, porém, para nominar tão somente a ação em massa de pessoas em prol de um objetivo comum.

No caminhar dos anos 70, a concepção de mobbing vai se revelando para Olweus (id.) insuficiente na tarefa de nomear o tipo de violência que ele desejava delimitar nos ambientes escolares. A certa altura, o estudioso conclui que essa ideia conferia ênfase demasiada a investidas grupais de natureza isolada, quando ele estava preocupado em refletir a respeito de embates de caráter sistemático entre indivíduos. Ademais, nem mobbing, tampouco mob, mostravam-se vocábulos adequados para que o pesquisador se comunicasse com os falantes da língua inglesa. Diante disso, seu primeiro livro do ano de 1973, quando publicado cinco anos mais tarde em inglês, buscou uma melhor tradução para esses termos, intitulando-se Aggression in the Schools: Bullies and Whipping Boys, que significa algo como "Agressão nas escolas: valentões e bodes expiatórios". A despeito da referência, o cientista ainda não delimita nessa obra uma definição estrita para o fenômeno que passaria a nominar por bullying.

Olweus $(i d$.$) relata que a conceituação apurada se evidencia imperativa apenas$ em 1983, quando o estudioso torna-se pivô de uma campanha nacional contra o bullying encabeçada pelo Ministério da Educação da Noruega. Essa iniciativa origina-se a partir de um "evento crítico" (Das, 2007) que toma forma no ano anterior: era 1982 quando vieram à tona os suicídios de três adolescentes, que teriam sofrido severas humilhações 
no universo escolar e a elas sucumbido. Esse chocante episódio conferiu vitrine aos estudos de Olweus, convocado então pelas autoridades a atuar como um agente-chave na campanha nacional (Olweus; Limber, 2010).

É nesse momento que o pesquisador elabora um questionário de investigação depois mundialmente conhecido como Olweus Bullying Questionnaire - de modo a realizar um diagnóstico no cenário escolar norueguês e, a partir dele, planificar intervenções. Para fins de aplicação desse instrumento, o bullying recebeu do cientista uma definição circunscrita, que viria a se dispersar globalmente. Tal conceituação, por conseguinte, enfatiza o caráter intencional e repetitivo de intimidações perpetradas por um ou mais estudantes contra um outro possuidor de parcos meios de defesa (Olweus, 2013).

Em fins dos anos 80, já reconhecido pelo protagonismo na campanha de enfrentamento norueguesa, Olweus é visitado por dois cientistas sêniores interessados em alavancar estudos sobre bullying em seus países: Kenneth Rigby, da Austrália e Peter Smith, do Reino Unido. Ambos levaram adiante a empreitada, sendo que Smith alcança uma notoriedade particular, em virtude de seus investimentos de pesquisa focados no cyberbullying (id.). Ademais, Smith torna-se conhecido por promover investigações comparativas transnacionais sobre bullying e cyberbullying, sendo um dos organizadores de uma precursora coletânea que procura fazer dialogar estudos ocidentais e orientais em tais temáticas (Smith; Kwak; Toda, 2016).

Nesse trabalho, o Japão, a Coreia do Sul e a China aparecem como os polos da pesquisa aplicada no Oriente. Ao contrário do Brasil, que adotou o estrangeirismo bullying, nesses três países vigoram termos específicos para a referência a esse tipo de violência - respectivamente, ijime, wang-ta, qifu (além de net-ijime para cyberbullying no Japão). Todos esses vocábulos, entretanto, abarcam um campo de significação semelhante ao de bullying, na medida em que procuram delimitar um tipo de agressão diferente do prejuízo físico aberto e isolado, caracterizada pela intencionalidade do ofensor, pela intimidação sistemática da vítima e pelo desequilíbrio de poder entre ambos (id.).

Embora registrem inovações locais, as investigações e intervenções antibullying sediadas no Oriente têm demonstrado uma inegável influência dos estudos pioneiros na região escandinava. Todavia, apesar dessa proximidade, Smith e seus colaboradores admitem a dificuldade de se estabelecerem comparações entre os dois lados do mundo 
devido a backgrounds socioculturais altamente distintos. Logo, eles recomendam que as pesquisas atuais prioritariamente quantitativas se somem a estudos qualitativos capazes de aprofundar o entendimento de alteridades $(i d$.$) .$

No Ocidente, a dominância científica mundial é hoje exercida pela Europa, pela Australásia e pela América do Norte. A Finlândia, por exemplo, mantém desde 2006 o KiVa Program, uma iniciativa antibullying escolar mundialmente prestigiada, implementada por uma parceria entre a Universidade de Turku e o Ministério da Educação e Cultura do país (id.). Os Estados Unidos, contudo, têm uma posição sui generis em tal contexto. Como observa o próprio Dan Olweus (2013), o debate sobre bullying nesse território revestiu-se de uma fascinação, que terminou por ultrapassar as fronteiras dos círculos acadêmicos e da gestão pública para alcançar o domínio popular, trajetória nesse ponto semelhante à brasileira.

Em uma das edições de um treinamento antibullying demandado por lei a todos os educadores do Estado de Nova York, a qual tive a oportunidade de etnografar, a ministrante tratou logo de alertar a audiência sobre essa atmosfera: "As pessoas falam tanto em bullying a ponto de se esquecerem que nem tudo é e que crianças, normalmente, têm conflitos entre si”’3. Essa massificação se configura de modo bastante recente, tendo em vista que o interesse estadunidense sobre bullying floresce apenas no início do século XXI, seguramente mais de uma década após as discussões se acalorarem no oeste europeu, na Austrália, na Nova Zelândia e no Canadá (Olweus, 2013; Smith et al., 2016). A explicação para essa cronologia reside em um "evento crítico" (Das, 2007) abordado a seguir, responsável pelo boom do tema em meio aos norte-americanos.

\footnotetext{
${ }^{3}$ O aparato legal que exige a capacitação referida é o Dignity for All Students - DASA Act, em efeito desde 2012.
} 
Columbine, 1999

Prezado Donald Trump,

Eu sou latino e, desde o meu primeiro dia nos Estados Unidos, eu tenho dado tudo de mim para fazer deste país o melhor. Eu tenho ajudado pessoas, cuidado das crianças e dos idosos doentes, vestido e alimentado desabrigados. Como você pode ver, MINHA AMÉRICA ERA GRANDE até você chegar... Minha única questão para você é: como você supõe querer fazer a América grande novamente se você é o homem número 1 em bullying e racismo neste país? Conte-me como, Sr. Trump.

Sinceramente,

Um homem latino que tem lutado contra o bullying e o racismo

Este bilhete, que despertou minha atenção etnográfica e foi por mim traduzido, estava afixado entre centenas nos corredores de uma das mais movimentadas estações do metrô nova-iorquino, numa mobilização coletiva batizada de Subway Therapy (Chung, 2016). Alavancada pelo artista Matthew L. Chavez, a iniciativa registrou massiva adesão da população da cidade, historicamente democrata, logo após a eleição do republicano Donald Trump à presidência dos Estados Unidos em 2016. Esse grande e colaborativo mural de recados expressou ansiedades, aspirações e também empatia para com aqueles segmentos que, segundo a opinião pública, haviam sido alvos de bullying por parte de Trump ao longo de sua campanha.

$\mathrm{O}$ termo bullying ganhou holofotes principalmente na fase final da acirrada corrida à Casa Branca, como meio de denominar - seja na mídia, seja no boca-a-boca comentários proferidos pelo então candidato Trump. Sob promessas de sepultar os efeitos de crises financeiras recentes e orientados pelo lema "Make America great again", os discursos do republicano incluíram ofensas misóginas, algumas especialmente endereçadas à sua oponente Hillary Clinton; ataques à legitimidade da cidadania de latinos e muçulmanos residentes no país; além da menção desabonadora a pessoas com deficiência. Paradoxalmente, em seu primeiro anúncio solo, a futura primeira-dama Melania Trump afirmou que, na vitória do marido, tomaria a luta contra o cyberbullying como missão (nesse sentido, $c f$. The Week, 2016).

Ainda antes do resultado final da eleição, a organização da sociedade civil Southern Poverty Law Center divulgou um relatório com os resultados de uma pesquisa sobre o "Efeito Trump" no cotidiano escolar norte-americano (Costello, 2016). A investigação realizou-se numa plataforma on-line entre educadores vinculados ao Teaching Tolerance, um dos projetos dessa instituição. Esses docentes relataram o 
aumento da prática de bullying contra estudantes cujas etnias e religiões haviam sido depreciadas na campanha eleitoral de Trump. Uma constatação, porém, menos óbvia foi a de que a retórica da disputa presidencial havia construído um "novo vocabulário de bullying", por meio do qual os alunos, de um modo geral, passaram a utilizar os nomes dos candidatos como pejorativos para provocar uns aos outros.

Os fatos antes descritos querem dar uma ideia da ubiquidade que a noção de bullying alcança hoje na cena pública norte-americana. Objetivam, ainda, sinalizar que essa presença pervasiva se dá recheada de contradições, que espelham hierarquias de poder e profundas desigualdades presentes nos Estados Unidos contemporâneo. Por conseguinte, somente a atenção às antinomias permite compreender como um país que se coloca hoje como uma potência em pesquisas, leis, políticas e projetos antibullying eleva à presidência um candidato tachado de "big bully" (Derber; Magrass, 2016).

As ideias do criador do construto em foco aqui começam timidamente a se dispersar pelos Estados Unidos em meados dos anos 90, com a chegada do Olweus Bullying Prevention Program (OBPP). Essa iniciativa, à época, já se encontrava bem estabelecida na Noruega, como resultado da campanha nacional contra a intimidação escolar promovida por esse país no início da década de 80. Em território estadunidense, o programa encontrou casa na Carolina do Norte, capitaneado pela psicóloga Susan Limber, associada à Clemson University, com quem Dan Olweus viria a desenvolver uma ativa parceria intelectual. De lá, a iniciativa difundiu-se para outros estados do país, pautada em reduzir e prevenir o bullying, bem como em melhorar relações entre pares, a partir de transformações no âmbito das "culturas escolares" (Olweus; Limber, 2010).

Não obstante, o debate norte-americano sobre bullying ganha de fato propulsão com a tragédia em Columbine High School, no Estado do Colorado, onde em abril de 1999 dois alunos abriram fogo contra colegas e professores, deixando uma série de mortos e feridos. Os adolescentes Dylan Klebold e Eric Harris foram os responsáveis pelo maior ataque armado a uma instituição de ensino até então registrado na história dos Estados Unidos. Ambos terminaram se suicidando a tiros na cena do crime (id.). A explicação pública para esse ato extremo alicerçou-se em sucessivas situações de humilhação e exclusão que os estudantes autores teriam sofrido na escola, reservadas aos weirds, losers e faggots, termos depreciativos da língua inglesa para pessoas tidas, respectivamente, por desajustadas, fracassadas e homossexuais. Altamente mediatizadas 
desde então, essas vivências foram referendadas em um livro de memórias lançado pela mãe de Dylan passados 17 anos do crime (Klebold, 2016).

Esse "evento crítico" (Das, 2007), portanto, é considerado por estudiosos um "turning point" na discussão norte-americana a respeito do bullying (Porter, 2013; Cornell, Limber, 2015). A conexão desse episódio com o suposto bullying vivenciado pelos assassinos encontra assim quase unanimidade. Uma voz dissidente advém do documentário assinado por Michael Moore (2002) cujo título em português é "Tiros em Columbine". Nesse filme, o cineasta posiciona uma enraizada cultura bélica existente nos Estados Unidos enquanto pano de fundo causal do ataque armado à escola no Colorado. O bullying, por conseguinte, não é sequer mencionado. Sob uma ótica sociológica, a argumentação de Moore se revela contundente, especialmente se pensada por meio de outro audiovisual que segue numa direção oposta.

O documentário intitulado "Bully" dirigido por Lee Hirsch (2011) - produção, que como "Tiros em Columbine", conquistou circulação mundial - estrutura-se a partir de um apanhado de histórias de crianças e adolescentes norte-americanos vitimados por bullying. Aspectos do belicismo estadunidense aparecem, de forma direta ou indireta, em diversos pontos dessa narrativa - em fatos, falas e objetos. Há, todavia, um caso emblemático: aquele protagonizado por Ja'Meya Jackson, estudante negra de 14 anos do Estado do Mississippi que, para revidar vexações experimentadas no ônibus escolar, ameaçou colegas com a arma da mãe pega às escondidas. A situação determinou a reclusão da garota em um centro de detenção juvenil. Em nenhum momento, entretanto, o filme procura cruzar, no contexto da intimidação, origem étnico-racial, mercado armamentista e política prisional, elementos absolutamente fundamentais para entender os meandros pelos quais o construto do bullying navega no panorama norte-americano.

Como ponto de inflexão na discussão sobre bullying nos Estados Unidos, a tragédia em Columbine determinou uma gama de consequências a partir dos anos 2000, em instâncias estatais, acadêmicas e civis. Dentre elas, está o aumento da judicialização de casos, nos quais, em geral, os pais passaram a sair em defesa de filhos vitimados e as escolas a receber acusações de negligência. Em conexão, crescem exponencialmente as legislações estaduais antibullying. Atualmente, embora não exista uma lei federal, apenas o Estado de Montana encontra-se desprovido de arcabouço jurídico na temática (APA, 2008; Cornell, Limber, 2015). 
A concretização sucessiva desses instrumentos legais, a despeito de diferenciados entre si, favoreceu diante do bullying escolar a operacionalização das chamadas "políticas de tolerância zero", nascidas nos anos 90 no âmbito da cruzada contra as drogas. Essa perspectiva, na qual a punição à indisciplina deve ser severa independente das circunstâncias, confere impulso à criminalização de atos classificados como bullying e abastece o fenômeno denominado "school to prison pipeline", ou seja, um fluxo contínuo de indivíduos encaminhados da escola à prisão (id.).

Esse cenário reverbera aquilo que Loïc Wacquant (2007) identifica como uma "onda punitiva" presente nos Estados Unidos contemporâneo. Proeminente "laboratório" de políticas neoliberais - fonte de inspiração para diversas nações, inclusas as da América Latina -, o governo norte-americano tem se apoiado fortemente numa "doxa penal" para desregulamentar mercados, depauperar empregos, justificar o avanço da pobreza e controlar "comportamentos desviantes" diante desse status quo. Essa estratégia desconsidera índices de criminalidade praticamente estáveis e se sustenta na dispersão de um "discurso alarmista" - mediado por autoridades públicas, supostos especialistas em violência e pela grande imprensa -, que mistura equivocadamente insegurança real com sensação de insegurança, seja de integridade física, estabilidade profissional ou de prestígio social.

Um notável resultado disso reside no vultoso incremento do sistema prisional estadunidense, que tem recebido, sobretudo, indivíduos negros e latinos, oriundo dos segmentos mais empobrecidos da população. Conforme expõe Wacquant (id.), estatísticas dão conta com clareza do encarceramento em massa promovido em território estadunidense. Mas, nesse sentido, prefiro destacar aqui um dado etnográfico, de modo a demonstrar os efeitos desse processo sobre as relações sociais. Ao dialogar reservadamente com a fundadora de uma organização da sociedade civil, focada na promoção de treinamentos antibullying na cidade de Nova York, ela confidenciou-me que, na sensibilização de crianças para atuarem enquanto "agentes de mudança" na escola, mostra-se fundamental trabalhar a diferença entre duas ações: "helping" e "snitching". No linguajar das ruas, snitch significa delator.

Esclareceu essa profissional: "Em certas regiões da cidade, as relações da população com a polícia são tensas. Eu não posso ser ingênua e fingir que isso não acontece. Muitos alunos resistem em trazer à tona situações de bullying pelo medo de serem vistos como alcaguetes, porque essa figura é altamente estigmatizada nas 
comunidades. Então, a gente precisa demonstrar que, ao tornar público casos de bullying, eles estarão não denunciando, mas sim ajudando as pessoas envolvidas". No workshop de prevenção que eu havia assistido antes dessa conversa, a audiência a receber tal mensagem não era aleatória: situava-se numa escola de um bairro negro, na qual o alunado só não era completamente composto de afrodescendentes por conta da presença pincelada de alguns latinos.

Trata-se, portanto, de uma "doxa penal” onipresente, a justificar não só o encarceramento, mas também investidas bélicas do país, por intermédio do estabelecimento de "tipos sociais" de periculosidade: o "estuprador" e o "traficante de drogas" entre negros e latinos; o "terrorista" entre os muçulmanos; como também o "bully", o sujeito "brigão" a habitar os ambientes de ensino. Sob essa ótica, a violência decorreria da imoralidade e da irresponsabilidade dos próprios criminosos, sem qualquer vínculo com o enxugamento estatal e o imperialismo em prol do avanço de mercados. No caso do setor educacional, Wacquant (ibid.: 71) argumenta que “... a encenação da violência escolar permite aos gerentes de Estado evitar o confronto com a desvalorização profissional e (...) [com a] crescente submissão do sistema de ensino à lógica da competição e aos imperativos da 'cultura de resultados' importada do meio empresarial".

No debate sobre bullying, essa torrente punitiva começa a receber contestações especialmente a partir da segunda década dos anos 2000. Um robusto relatório da National Academies of Sciences, Engineering, and Medicine (Flannery et al., 2016), por exemplo, enfatizou inconsistências nas pesquisas, políticas e intervenções antibullying nos Estados Unidos. Esse pool de pesquisadores advoga que o combate do bullying não perfaz apenas um desafio educacional ou uma questão de direitos humanos, mas sim problema de saúde pública. Ancorados em estudos neurocientíficos - que, segundo eles, ainda carecem de aprofundamento -, esses cientistas referendam que indivíduos envolvidos em situações de bullying, sejam vítimas ou agressores e até mesmo as testemunhas, mostram maior propensão a traumas, a doenças, ao suicídio e à delinquência. As "políticas de tolerância zero" teriam mostrado, ao longo do tempo, potencial de contribuir e não de decrescer a gravidade desse quadro. 
Diante disso, há a recomendação de descontinuar iniciativas desse tipo. A defesa é por programas de prevenção cientificamente respaldados, com enfoque "ecológico", ou seja, que situem os eventos de bullying não só na dimensão da convivência entre pares, mas também contemplem a influência das relações estabelecidas nas escolas, famílias e comunidades. Ademais, nesse panorama, o grupo de estudiosos apoia a implementação de programas pedagógicos voltados ao desenvolvimento de competências socioemocionais (id.). Nessa perspectiva, encontra-se em curso um movimento educacional denominado Social and Emotional Learning (SEL), cuja proposta é auxiliar crianças e jovens a elaborarem habilidades socioemocionais que melhorem a aprendizagem individual e os relacionamentos sociais. Nesse conjunto de recursos, despontam a autoconsciência, o autocontrole, a empatia, a cooperação e a responsabilidade pessoal. Trata-se de uma abordagem considerada por cientistas e educadores, nos Estados Unidos e em outras nações ocidentais, como congruente com o enfrentamento do bullying (Porter, 2013; CASEL, 2016).

Todavia, a tônica do aprendizado socioemocional, embora com um receituário diferente daquele prescrito pelas "políticas de tolerância zero", acaba por manter intacto o cerne destas últimas. Na esteira das análises de Nikolas Rose (2007) desde os Estados Unidos contemporâneo, verifica-se que ambos os aportes, provenientes de uma governamentalidade neoliberal, calcam-se em uma suposta epidemia de condutas anticivilizadas a comprometer a vida em sociedade, decorrentes de carências morais inerentes a sujeitos suspendidos de contextos sociológicos.

A abordagem focada em habilidades socioemocionais, por seu turno, explora com mais propriedade uma "biologia do controle", posto inserida em uma política de saúde pública voltada ao combate da violência pelo gerenciamento do risco. Tal proposta apoia-se nos avanços mais recentes da neurociência que, pela articulação de saberes biomédicos e psicossociais, fomenta a esperança de determinar níveis individuais de propensão à agressividade e, consequentemente, promover a "proteção" do contingente de sujeitos considerados "normais" (id.).

Dentre as diversas formas de operacionalizar essa política está a identificação de zonas nas quais o risco revela-se passível de mensuração, como as escolas por exemplo, onde crianças e adolescentes podem ser observados, testados e monitorados, não por figuras disciplinares como no passado, mas sim por mecanismos científicos de susceptibilidade, predição e prevenção. Tal quadro mobiliza uma gama de profissionais 
- neurocientistas, geneticistas, psicólogos, psiquiatras, policiais, assistentes sociais, professores etc. - com a "obrigação de governar e de ser governados", em detrimento de uma discussão assertiva sobre as devastadoras transformações socioeconômicas alavancadas pela racionalidade neoliberal (id.).

Um exemplo de rebatimento desse viés de intervenção na realidade brasileira reside na controvérsia gerada por uma proposta de medição massiva de "competências socioemocionais", cujo espaço de experimentação foi a rede estadual de ensino do Rio de Janeiro (Santos; Primi, 2014). Respaldada por órgãos federais de educação, essa propositura de política pública teve criação assinada pelo Instituto Ayrton Senna e pela Organização para a Cooperação e Desenvolvimento Econômico (OCDE), ambas entidades suportadas por grandes corporações ${ }^{4}$.

Em uma carta pública, a Associação de Pós-graduação e Pesquisa em Educação no Brasil repudiou tal proposição, especialmente quanto à característica de medição em larga escala de atributos não cognitivos de crianças e jovens (ANPED, 2014). Nesse documento, dispersado on-line, a entidade declarou:

[O] estabelecimento de uma hierarquia valorativa, pretensamente universal e imparcial, expressa a desconsideração da desigualdade social [,] econômica e [d]a diversidade cultural da sociedade brasileira, bem como [d]as diferenças entre os sujeitos, o que possivelmente representa a naturalização de valores oriundos das classes mais favorecidas socioeconomicamente. $\mathrm{O}$ que se busca é a padronização desses valores? [A]s avaliações em larga escala vêm se constituindo como uma das principais estratégias de consecução de uma lógica de gestão da educação que, em nome da promoção do desenvolvimento dos alunos, recorre à comparação de seus níveis de proficiência e à sua classificação e premiação. O que poderá resultar da avaliação de habilidades socioemocionais: premiação daqueles alunos que se conformarem aos valores estabelecidos? Segregação e discriminação daqueles que não apresentam as habilidades tomadas como as necessárias para uma sociedade "melhor"? Quem decide sobre qual é a "melhor sociedade" são os elaboradores dos itens dos testes?

\footnotetext{
${ }^{4} \mathrm{O}$ referido instituto define-se como entidade sem fins lucrativos que atua em prol da ampliação de oportunidades ao público infanto-juvenil através da educação ( $c f$. www.institutoayrtonsenna.org.br). A OCDE, por sua vez, é um organismo de articulação política internacional que reúne 35 países, dentre eles o Brasil (cf. www.oecd.org).

${ }^{5}$ Ainda haveria uma segunda carta aberta da ANPED (2015), em resposta a declarações da presidente do Instituto Ayrton Senna, Viviane Senna, numa conversa com o jornal Folha de S. Paulo, em 17/06/15. A manchete da entrevista traz a seguinte fala: “'Educação é baseada em achismos, não em ciência', diz Viviane Senna". Nessa segunda carta, a Anped demonstra preocupação com investimentos do Instituto em pesquisas de fundo neurocientífico, associadas a estudos econômicos, numa atmosfera favorecedora do mercantilismo educacional.
} 
Com esses desconcertantes questionamentos em mente, quero agora adentrar a análise da empresa moral do bullying no cenário brasileiro, à luz das repercussões do "evento crítico" (Das, 2007) materializado na Escola Municipal Tasso da Silveira, na cidade do Rio de Janeiro.

\section{Realengo, 2011}

Eu quero deixar claro que eu sou contra as guerras ou qualquer que sejam os atos de violência sem motivo justo. Eu também quero deixar bem claro que eu não sou responsável por todas as mortes que ocorrerão. Embora meus dedos serão responsáveis por puxar o gatilho, cada vez que vocês verem alguém ridicularizando uma pessoa por sua aparência física, vestimenta ou qualquer que seja o motivo; cada vez que verem alguém sendo humilhado e agredido injustamente; cada vez que verem alguém sofrendo preconceito ou sendo discriminado; cada vez que verem alguém se aproveitando da bondade ou da inocência de alguém, lembrem-se de que esse tipo de pessoa foram [sic] responsáveis por todas essas mortes, inclusive a minha. (...)

A luta pela qual muitos irmãos morreram e eu morrerei não é exclusivamente pelo que é conhecido como bullying. A nossa luta é contra pessoas cruéis, covardes, que se aproveitam da bondade, da inocência, da fraqueza de pessoas incapazes de se defenderem. (...) Os irmãos observaram que eu raspei a barba. Foi necessário, porque eu já estava planejando ir no local para estudar, ver uma forma de infiltração. Eu já tinha ido antes, há muitos meses atrás [sic], eu fui, eu ainda não usava barba. Eu fui para dar uma analisada. Hoje é segun... terça-feira, aliás. Eu fui ontem, segunda. Hoje é terça-feira, dia 5. (...)

Dois dias depois, na manhã de 07 de abril de 2011, Wellington Menezes de Oliveira, o autor dos trechos antes transcritos, retornaria à Tasso da Silveira, instituição municipal de ensino do bairro de Realengo, zona oeste do Rio de Janeiro, sob a justificativa de dar uma palestra aos estudantes, na condição de egresso. Mas o propósito da visita, como se depreende de suas próprias palavras, era outro. Na mochila que carregava, encontrava-se o armamento com o qual ele abriria fogo contra alunos acomodados em suas salas de aula, prontos para começar mais uma jornada escolar.

Os relatos publicitados da investigação do crime dão conta que Wellington, na casa dos 20 anos, após fazer uma dúzia de vítimas fatais e deixar feridos, suicidou-se com um tiro na cabeça, quando já em fuga da polícia. Soube-se que ele, embora tenha crescido em Realengo, vivia à época do crime sozinho em Sepetiba, bairro também na zona oeste do Rio de Janeiro, numa casa pertencente à sua mãe adotiva, já falecida. À vizinhança, mostrava-se um morador reservado, afeito a assuntos religiosos e apreciador de jogos on-line. No computador pessoal do rapaz, a polícia encontrou vídeos, aparentemente gravados por ele próprio, nos quais Wellington fala sobre as motivações 
e o planejamento do ato criminoso que praticaria (Ritto, 2011; Jornal da Globo, 2011; R7, 2011).

Os dois excertos outrora apresentados são parte desse conteúdo, viralizado na Internet, no qual o termo bullying aparece mencionado em negação pelo autor. Ele diz: “A luta pela qual (...) eu morrerei não é exclusivamente pelo que é conhecido como bullying". A despeito da negativa, a menção que o homicida faz ao termo, associada aos relatos de ex-colegas dele acerca das vexações que sofria na escola, configuraram materiais suficientes para conectar de modo inextrincável o "Massacre de Realengo" como o episódio se tornou conhecido - ao bullying que, a partir de então, se consolida na sociedade brasileira como um fenômeno de violência digno de atenção.

Quando em 2011 ocorreu o "Massacre de Realengo", a leitura imediata desse acontecimento se deu a partir dos elementos que cercaram o ataque armado à escola norte-americana do Colorado, doze anos antes. Uma rápida busca on-line revela uma série de textos noticiosos da época a classificar o episódio como a "Columbine brasileira”. Na mesma linha, reportagens recentes, que procuraram averiguar os desdobramentos do crime em Realengo na vida de sobreviventes e de famílias das vítimas fatais, rendem continuada ênfase à comparação com o episódio estadunidense (nesse sentido, $c f$. Borges, 2015).

Como resultado da tragédia carioca, pais, familiares e amigos dos jovens assassinados fundaram a Associação Anjos de Realengo. A entidade, na medida em que trabalha pela salvaguarda da memória das vítimas, tem tomado por bandeiras a promoção da segurança nas escolas e o combate ao bullying ${ }^{6}$. Na visão desse coletivo, a obtenção de ambientes educacionais seguros se daria pela realização contínua de atividades pedagógicas antibullying, como também pela inserção definitiva de profissionais como psicólogos, assistentes sociais e porteiros no quadro de funcionários das instituições de ensino, focalizados em prevenir a concretização de episódios de violência.

A associação expressa assim concordância com o pressuposto - comum à leitura pública tanto da tragédia de Realengo quanto de Columbine - de que o sofrimento psíquico causado pelo bullying coloca-se como fator de motivação para atos violentos. Entretanto, embora lance mão do construto nessa forma tradicional para dar cabo de

\footnotetext{
${ }^{6} C f$. www.facebook.com/osanjos.derealengo.
} 
suas reivindicações, minha interpretação antropológica é que a entidade não o faz, inusitadamente, de forma alinhada ao mainstream.

Esse agenciamento peculiar - que toma a noção de bullying como artifício para tornar expostas feridas da sociedade brasileira, aprofundadas em tempos neoliberais toma corpo especialmente no ativismo de Adriana Silveira, presidente da Associação Anjos de Realengo e mãe de Luiza Paula, adolescente cuja vida interrompeu-se aos 14 anos. Dar-se conta dessa agência particular foi possível a partir do encontro etnográfico que travei com Adriana e seus companheiros de luta, quando das solenidades em memória das vítimas passados cincos anos da tragédia, o qual passo a descrever.

\section{Realengo, 2016}

Era minha primeira vez naquele espaço, mas este não surgia estranho a mim, nem aos milhares de espectadores que fizeram do filme "Tropa de Elite 2" um sucesso de bilheteria, quando lançado em 2010 pelo cineasta José Padilha. O plenário da Assembleia Legislativa do Estado do Rio de Janeiro (Alerj) abrigou uma cena emblemática desse audiovisual, na qual transcorrem os tensos trabalhos de uma comissão parlamentar de inquérito, a investigar as escusas conexões políticas e a atuação violenta de milícias em meio à população de baixa renda no território fluminense. O evento que eu assistiria ali, a despeito de ter outro propósito, igualmente traria à tona mazelas da violência urbana que sitia o Rio de Janeiro, assim como outras cidades brasileiras.

A Sessão Solene em Homenagem às Vítimas da Escola Municipal Tasso da Silveira começou às $19 \mathrm{~h} 30$, com uma hora de atraso. Os principais convidados do evento haviam partido de Realengo no final da tarde em um ônibus fretado e, impedidos pelo caótico tráfego carioca, não conseguiram chegar mais cedo ao centro da cidade. Ao ingressarem coletivamente no plenário da Alerj, os familiares e amigos das vítimas vocalizaram de imediato uma mensagem, estampada nas camisetas que trajavam: "Quem não conhece a história... repete seus erros! Anjos de Realengo pedem paz. Cinco anos de saudades". A eles, estavam reservados os assentos das primeiras filas da assembleia, onde se acomodaram para o início da sessão. 
A solenidade, presidida pelo deputado Iranildo Campos, foi protocolarmente aberta com o convite para um minuto de silêncio em homenagem às vítimas, acompanhado por toque de corneta, seguido pela execução do Hino Nacional. No entremeio, o presidente anunciou os convidados a compor a mesa diretora. Além dele, dois outros homens corporificavam a presença do Estado nesse rol: Sanjeev Chowdhury, Cônsul Geral do Canadá no Brasil e entusiasta da Associação Anjos de Realengo, como também Marcio Alexandre Alves, subtenente da Polícia Militar do Estado do Rio de Janeiro. À época da tragédia no posto de sargento, Alves conduzia no dia do crime uma blitz nas imediações da Tasso da Silveira, quando se viu envolto pelo pedido de socorro de um aluno que, mesmo baleado, havia conseguido fugir da escola e pedir ajuda. O sargento então tornou-se conhecido por ter sido o primeiro policial a atender à ocorrência, alvejando o criminoso que terminou por tirar a própria vida.

O restante da mesa foi todo composto por mulheres, ativistas em direitos humanos: Adriana Silveira, presidente da Associação Anjos de Realengo; Margareth Silva, presidente do Instituto Nacional de Vítimas de Violência; Juciara de Abreu e Silva Campos, presidente da organização não governamental Harmonia da Vida e Iracilda Toledo, presidente da Associação de Familiares da Chacina de Vigário Geral. Por fim, o grupo contou com um membro inabitual: a filha de cinco anos do deputado Campos. Nas palavras dele, sua convidada especial "em respeito a todas as crianças que foram vítimas dessa bárbara violência que aconteceu na nossa cidade, no nosso Estado, no nosso país".

Exceto pela presença incomum de uma criança, a composição dessa mesa não surge fortuita. Reflete um antagonismo perpassado pelo gênero que, segundo Adriana Vianna e Juliana Farias (2011), se revela recorrente nas mobilizações por justiça encabeçadas por famílias vitimadas pela violência urbana no Brasil. Trata-se do embate entre duas "entidades discursivas" fundamentais - "as mães" e "o Estado" -, capaz de emergir mesmo numa sessão solene, marcada pela reverência e não pelo confronto aberto. Sob essa luz, o polo feminino, "das mães”, aglutina simbolicamente não apenas mulheres, mas quaisquer indivíduos que, em seu ativismo, denunciam a sociabilidade doméstica desmantelada pela violência. No polo masculino, por sua vez, está contraposto "o Estado", gerenciado prioritariamente por homens, em administrações não raro incompetentes e, portanto, permissivas dessa mesma violência. 
Tal enfrentamento - que, a um só tempo, reflete e desafia inequidades de gênero calcificadas nas próprias relações sociais - abastece-se pelo constante "acionamento da condição de mãe de vítima de violência”. A exposição desse status legitima o discurso público "das mães", posto tornar manifesto um vínculo soberano, moralmente indiscutível, na cultura ocidental: o laço entre progenitoras e seus filhos, no âmbito do qual homens e mulheres, indistintamente, aparecem implicados (id.).

Foi justamente essa condição que Adriana operacionalizou quando convocada a falar na sessão solene. Disse ela: "Depois de cinco anos, nós ainda continuamos na luta, não desistimos de lutar pela segurança nas escolas e contra o bullying, o mal do século. Hoje, nós, com muita dificuldade, mas com muita força, em memória e em nome dos nossos filhos, continuamos de pé por eles, para que haja uma mudança na educação. $\mathrm{E}$ queremos contar com essa Casa para nos apoiar nessa mudança tão necessária em nosso país”. Logo, Adriana modela-se enquanto ativista a partir da maternidade como fato: é uma mãe que luta pelo resguardo da memória não só da sua filha perdida, mas dos filhos dos outros pais assolados pela tragédia em Realengo; é também mãe que luta contra o bullying nas escolas pela segurança dos filhos dos demais.

O papel, infelizmente, não permite nem sequer esboçar aqui o olhar, a dicção, a respiração com que Adriana deu vida a seu enunciado. Estremecidas, mas sobretudo eloquentes, as palavras dela revestiam-se de uma carga ao mesmo tempo afetiva e cognitiva que, como argumenta Deborah Gould (2010), configura-se como combustível de toda mobilização política. Tal combinação, longe de ser fruto de irracionalidade, constitui uma "força motivacional" para quaisquer intervenções sociais, sejam planejadas, sejam contingenciais. É nesse panorama que a agência da noção de bullying ganha no discurso de Adriana uma roupagem não psicologizante, que foge do convencional.

O ativismo dessa mãe se revela movido por aquilo que Veena Das (2007) denomina por "conhecimento venenoso": aquele gerado pelo sofrimento de ter um modo de vida completamente arrasado pela violência. A atuação pública de Adriana põe em evidência sua forma de "habitar novamente um espaço devastado", desde onde não se extingue o "conhecimento venenoso", posto impossível, mas se trilha a vida nos interstícios dele recriando sociabilidades cotidianas. Das explica que "reabitar" o mundo nesses termos desafia caminhos estandardizados de viver o luto num contexto 
contemporâneo de traumatismo difuso, em que buscas solitárias transcendentes ou medicalizadas para dar conta do sofrimento são percebidas como as mais naturais.

Como aponta essa autora, ao "descender ao ordinário", ativistas como Adriana lançam-se a uma delicada e laboriosa "re-narração" de suas histórias pessoais, no interior da qual "signos nocivos de violação", embora nunca plenamente ausentes, vão sendo domesticados ao longo do tempo. Nesse sentido, asseverou Adriana em uma entrevista sobre o lançamento de um livro infantil, que escreveu em homenagem à filha: "Eu não podia, depois de tudo que aconteceu, me trancar num quarto e morrer junto com ela" (Estúdio i, 2016). Mostra-se impossível saber como esse processo se desenvolveria caso o assassino dos jovens em Realengo tivesse saído vivo do crime que cometeu. O fato é que, no discurso de Adriana, não há lugar para idiomas de vingança pessoal ou de punição por vias legais. Tal fala perpassa-se, sim, por um conteúdo de justiça, porém, não numa dimensão judiciária, mas social.

Para dar sequência a essa argumentação, explorarei o conteúdo dos demais pronunciamentos que tomaram lugar na Sessão Solene em Homenagem às Vítimas da Escola Municipal Tasso da Silveira. Sempre em relação à voz de Adriana, examino como o agenciamento do bullying se manifesta nessas outras falas, sob diferentes formas e intensidades. Busco, desse modo, expor implicações semântico-pragmáticas dos usos desse construto, no âmbito da tensão com feições de gênero estabelecida entre "as mães" e o "Estado" enquanto polos discursivos, na esteira da abordagem de Vianna e Farias (2011), outrora apresentada.

\section{O polo estatal}

A sequência de discursos dos convidados da mesa diretora sofreu uma interrupção com o ingresso inesperado em plenário de um membro da Casa, o deputado Coronel Jairo, a quem a palavra foi concedida. É com trechos do discurso desse parlamentar que dou início à exposição das falas integrantes do polo masculino no antagonismo antes mencionado, aquele ocupado pela figura do "Estado". Coronel Jairo apresentou-se como morador e representante da zona oeste carioca, onde está o bairro de Realengo. Segundo ele, uma região geograficamente afastada do centro das decisões públicas e, portanto, ainda carente de benesses estatais. $\mathrm{O}$ deputado principiou dizendo: 
Queria dar boa noite e dizer da minha alegria de estar aqui nesse momento, que não é muito alegre porque faz recordar uma covardia que um louco fez lá em Realengo contra as nossas crianças. (...) Eu quero cumprimentar as famílias, sei que não existe solução pra isso, essa dor é muito forte, a gente sabe, um filho, uma filha, o valor que tem dentro do peito. Eu tenho um chefe de gabinete (...) que perdeu um menino agora (...) com uma doença grave. Quando então, através de um monstro, um covarde invade a escola onde a gente sempre imagina que os nossos filhos estão protegidos e ceifa a vida de um adolescente, é muito pior, é muito grave. Mas tenho certeza também que o próprio poeta, Nosso Senhor Jesus Cristo, só dá o fardo que podemos carregar. (...) Eu quero que vocês creiam, tenho certeza absoluta, que Deus, quando permite isso, é porque Ele tem uma missão pros vossos filhos. Vossos filhos talvez estejam hoje representando e salvando vidas ao lado do Criador.

Terminado tal discurso, os trabalhos da mesa retomaram a normalidade com a fala do subtenente Marcio Alexandre Alves, a primeira autoridade acionada para atender a ocorrência na Escola Tasso da Silveira. Um conjunto de ambivalências perpassou esse pronunciamento. De um lado, Alves buscou posicionar como herói dos acontecimentos o estudante Alan Mendes Ferreira que, mesmo baleado, deixou o colégio para buscar ajuda e acabou por encontrar o policial numa blitz nas imediações. "Queria eu ter chegado minutos antes, ter evitado isso, ter parado o Wellington [o assassino] na rua, ter feito uma revista e encontrado aquelas armas com ele, ele não chegaria à escola e nada disso teria acontecido", externou.

Por outro lado, dirigiu-se ao Cônsul Geral do Canadá no Brasil, que compunha a mesa, para assinalar: "Em 2015, eu recebi uma medalha do seu país, de um grupo antiterrorismo. (...) Por incrível que pareça, aqui do nosso Estado eu não tenho [uma medalha], mas o seu país, bem distante daqui me agraciou, mas aqui do nosso Estado eu não tenho nenhum tipo de condecoração". Por fim, completou em defesa da segurança escolar: "Hoje nós temos o Proeis [Programa Estadual de Integração na Segurança], onde a Polícia Militar atua nas escolas, mas devido à crise que nós estamos tendo [no país], alguns policiais estão deixando de trabalhar porque não estão recebendo [seus salários]".

O último componente da mesa a se manifestar foi o deputado Iranildo Campos, que presidiu a sessão solene. De saída, o parlamentar anunciou que acabava de receber a notícia da aprovação definitiva Lei Federal n. 13.277 de 2016, a qual declara a data de 07 de abril, dia do ataque armado em Realengo, como Dia Nacional de Combate ao Bullying e à Violência na Escola. "Já podem ter a certeza de que eu vou tentar incluir no calendário oficial do Estado do Rio de Janeiro essa data. Até porque, as informações 
que nos chegaram, na época dessa tragédia, é que o Wellington é um ex-aluno dessa escola e que ele tinha uma revolta porque ele sofreu bullying nessa escola", afirmou.

Adiante, destacou, em referência aos Estados Unidos: "No nosso país isso é novidade. Nos países americanos [sic], os alunos compram arma em qualquer lugar, chegam na escola e matam 10, 20, 30 colegas, fazem chacinas. Normalmente, a gente vê isso no noticiário internacional. Aqui no nosso país não tem isso. (...) [A] gente vem daquela época antiga, da nossa formação familiar que não existia violência, no máximo era briga de rua e a gente vê a violência crescer cada dia. (...) Mas quando fala em criança, gente, é muito dolorido", disse Campos que, em seguida, silenciou por um momento para conter o choro. Pouco depois, prosseguiu:

É a primeira vez que essa Casa está fazendo uma sessão solene em homenagem a crianças de quem a vida foi covardemente retirada. (...) É muito fácil homenagear jogador de futebol ou artista, o poeta, enche de gente. Mas quando eu vejo hoje uma homenagem para essas crianças, eu vejo pessoas com dor no coração, que vieram aqui às vezes até pra se encontrar, que eu sei da associação que vocês têm, (...) das mulheres. (...) E vocês façam essa observação, homens: que a maioria das brigas no nosso país, nas lutas pelos direitos humanos da sociedade, principalmente das crianças, é a mulher que está de frente. Poucos políticos, homens, botam a cara, se envolvem nisso, não sei por quê. (...) Naquele momento [da tragédia], o prefeito do Rio de Janeiro se preocupou e contratou alguns porteiros para ficarem nas escolas, que hoje não estão mais trabalhando. (...) Tudo bem, não pode o porteiro, bota detector de metal, por que não bota um guarda municipal? (...) A vida das nossas crianças não é competência dos políticos resguardar a sua integridade? Na hora que a mãe ou o pai deixa uma criança na escola, eles acreditam que a criança está segura. E aí acontece isso. Até quando a gente vai ficar nessa dúvida?

\section{O polo maternal}

O discurso do deputado Campos foi então interrompido. Cristina Leonardo, que atuou como advogada dos vitimados pelas chacinas da Candelária e de Vigário Geral, pediu a palavra ${ }^{7}$. Com a exposição dela, gostaria de demarcar a apresentação aqui de relatos do polo discursivo feminino, aquele cristalizado pela figura das "mães" (Vianna; Farias, 2011). Cristina dirigiu-se, com fina ironia, ao deputado: “Eu gostaria de fazer uma sugestão ao senhor. Porque poucos deputados no Rio de Janeiro olham com tanto carinho como o senhor está olhando para as vítimas de violência. (...) Eu gostaria de

\footnotetext{
${ }^{7}$ As chacinas da Candelária e de Vigário Geral são crimes de ódio que aconteceram no Rio de Janeiro no ano de 1993, num intervalo de cerca de um mês. Na primeira, moradores de rua que dormiam nas escadarias da Igreja da Candelária foram alvejados por um grupo de policiais e oito terminaram assassinados. Na segunda, 21 residentes da favela de Vigário Geral acabaram executados por um grupo de extermínio, que também contava com membros da polícia. Ainda em comum, as duas tragédias têm entre si o perfil das vítimas: a maioria compôs-se de jovens, negros e pobres. Além disso, a impunidade dos criminosos configura um traço a assemelhar os dois episódios.
} 
sugerir ao senhor que pensasse num projeto de lei para essas questões das escolas. Já que o senhor está falando sobre isso, acho que essa é a Casa, acho que esse é o momento do senhor pensar nessa reivindicação das mães".

Pego de surpresa, o parlamentar driblou a colocação de Cristina argumentando que concretização de uma lei não é um processo simples, especialmente no que tange à delimitação orçamentária de implementação. Cristina retrucou: "Tem emenda de gabinete pra Copa do Mundo, tem emenda pras Olimpíadas e, nesse momento, eu acho que isso seria uma prioridade, porque a educação em primeiro lugar, esse país só vai mudar com educação". Pressionado, o deputado se prontificou a apresentar uma indicação legislativa na Assembleia pela instalação de detectores de metais em todas as escolas públicas estaduais.

Pouco antes da sessão se encaminhar para sua parte final, quando os familiares das vítimas receberiam placas e flores em homenagem, houve uma nova quebra de protocolo. Adriana, enquanto presidente da Associação Anjos de Realengo, solicitou espaço de fala. A manifestação dela, nessa oportunidade, diferenciou-se da primeira prevista pelo roteiro da sessão. Dessa vez, as palavras de Adriana libertaram-se do tremor para, com uma assertividade político-afetiva (Gould, 2010), voltar-se ao deputado:

Eu gostaria de manifestar aqui um fato com que nós viemos lutando todo esse tempo. Nós, desde que perdemos nossos filhos, viemos lutando, unimos as nossas forças. Dizem que morto não tem voz; a minha Luiza tem voz. Eu sou a voz da minha filha. Eu sou a voz destas onze crianças, com a minha doze, que perderam a vida na chacina de Realengo. Nossos filhos perderam a vida dentro de uma escola, estudando. Nossos filhos não estavam numa festa, nossos filhos não estavam em lugar nenhum pra que alguém dissesse que foi uma fatalidade. Eu não posso admitir que crianças que estão dentro da escola estudando, com o seu caderno, com seu lápis, sua borracha, sejam executadas. Nossos filhos foram mortos como bandidos, foram executados com seus cadernos, com seus lápis, dentro de uma escola do município. E o que aconteceu depois disso? Tentam fazer nós engolirmos que nossos filhos estavam dentro da escola e que foi uma fatalidade. Eu não posso engolir isso, eu não posso aceitar. Sabe por quê? Porque a escola foi feita pros nossos filhos, pra todas as crianças, irem em busca de um futuro promissor. Lugar de criança é dentro da escola. Se você não põe seu filho dentro da escola, você é convidado a comparecer ao Conselho Tutelar. E quando você põe seu filho dentro de uma escola e ele vem perder a vida dentro dessa escola, eu pergunto: o que têm a nos dizer, que foi uma fatalidade? Isso é resposta? Em nome das nossas crianças, em nome da minha filha, nós vamos pedir ao senhor, encarecidamente, que vire lei no nosso Estado que no dia 07 de abril em todas as escolas, tanto municipais quanto estaduais, existam trabalhos falando sobre a violência e contra o bullying. Hoje a nossa luta não é mais pelos nossos filhos, porque não estão mais dentro da escola. Hoje a nossa luta é pelos filhos dos nossos vizinhos, é pelos nossos amigos e pelos nossos parentes. $\mathrm{O}$ nosso ensino público está uma vergonha. O mínimo que as autoridades têm a fazer por nós é que haja mudança na educação. Então, eu acho que o dia 07 de abril de 2011 foi a pior tragédia que aconteceu no nosso país, abalou o 
mundo inteiro. E o que foi feito depois disso? Nada. Nada foi feito depois do dia 07 de abril. Só a minha vida e de todas essas famílias que mudou. Então, eu lhe peço deputado, se comprometa conosco, com carinho, de pensar na nossa proposta, que ela vire a Lei Anjos de Realengo, é tudo que nós queremos.

\section{Um construto na berlinda}

A agência do bullying nas falas outrora destrinchadas sinaliza a existência de disputas semióticas em torno dessa noção, a exemplo do que John F. Collins (2015) verifica em uma etnografia sobre os processos de construção de ideologias raciais no Brasil. Fundamentado pela perspectiva peirceana, Collins advoga que atentar para o desenvolvimento de tais confrontos coloca-se como algo fundamental, posto eles exercerem efeitos concretos sobre a vida cotidiana e sobre a produção da história. Segundo o autor, esses embates falam da instauração de certos "regimes de disciplina e normalização" sobre os sujeitos, como também da insubordinação a essas formas de governo mesmas.

Iluminada por tais reflexões, a narração etnográfica aqui exposta evidencia que o vocábulo bullying, enquanto um significante, adquire significados radicalmente diferenciados a depender da posição de quem o interpreta nos discursos apresentados. Nesse panorama, as tensões incrementam-se diante do fato de estar em disputa semiótica uma palavra anglófona, que não encontrou no português do Brasil uma tradução bem estabelecida.

Aos pronunciamentos situados no polo discursivo estatal, é fundante a figura de Wellington Menezes de Oliveira enquanto criminoso responsável pelo ataque armado à escola em Realengo. Nesse quadro, a acepção de bullying serve para sustentar um "diagnóstico como explicação" (Bezerra, 2011) para a tragédia. Sob tal ótica, o bullying sofrido na época de estudante teria propiciado um desajuste psíquico de monta em Wellington, tornando-o o "louco", o "monstro", o "covarde" que veio a se vingar por meio de uma chacina.

Essa interpretação procura destacar o caráter extraordinário desse evento em nosso país. Dessa maneira, compartilha de uma negação assinalada por Leandro Karnal (2011), ao rememorar o clássico "O homem cordial” de Sérgio B. de Holanda (1995 [1936]): aquela referente à contrariedade da sociedade brasileira em se ver como violenta. Segundo Karnal, essa "narrativa pacifista" a compor a identidade nacional possui uma contraface, conformada pelo exercício de agressividades cotidianas, 
geradoras de vínculos grupais segregacionistas. Tal fenômeno pode ser observado desde as atividades mais triviais do dia a dia do brasileiro - basta assistir à programação televisiva, movimentar-se pelo trânsito ou ir a um jogo de futebol. Afirma o autor: “Temos ódio ao ódio, apesar de ele nos seduzir".

Para Karnal (id.), tal recusa da violência conecta-se a dois fatores históricos essenciais. O primeiro de que no Brasil nunca teriam existido guerras, mas somente "agitações", uma quimera que os registros provam inverdade. O segundo assenta-se numa infiltrada tradição cristã na cultura nacional, a afirmar a ira como pecado e o perdão enquanto exigência. Ecos dessa ideologia religiosa manifestam-se na atuação estatal não apenas em palavras de discursos como os antes apresentados, mas em signos diversificados. "Sob a proteção de Deus declaro aberta a Sessão Solene em Homenagem às Vítimas da Escola Municipal Tasso da Silveira", anunciou o deputado Iranildo Campos no início do ato público em análise aqui. Nessa fala, às costas do parlamentar, uma imagem de Nossa Senhora Aparecida, além de um vultoso crucifixo no alto do plenário da Alerj. Trata-se de uma cena nada incomum nos universos da ação estatal que, em tese, deveria ser laica.

Se, para os entes estatais, a explicação do massacre em Realengo modela-se pelo diagnóstico, a solução para evitar a repetição desse tipo de episódio deve advir do incremento do aparato repressivo, cristalizado na proposta de reforço do policiamento escolar e da instalação de detectores de metais. Na contramão disso, mostra-se plausível recordar o constatado por Michel Misse (2006): os dispositivos de polícia só podem ser eficazes onde o crime é excepcional. Esse, contudo, não indica ser o caso brasileiro.

Para compreender e agir sobre a violência, aponta Misse (id.), é necessário forçar o olhar para fatores macroestruturais de âmbito nacional, tais como o inchaço urbano desordenado, a insegurança da empregabilidade, a obsolescência do sistema judiciário e a depauperação do sistema educacional. Ademais, há que se incluir nessa caldeira o impacto de mecanismos internacionais de governo, como os neoliberais da atualidade. Conforme alerta Norbert Elias (1997), em contexturas assim têm-se não apenas conflitos socioeconômicos, mas também geracionais, tendo em vista que principalmente os jovens de estratos mais desfavorecidos da população tendem a encontrar severas dificuldades em identificar caminhos para um "futuro pleno de significado". 
É sobre esse panorama que os discursos aglutinados no polo feminino lançam holofotes. Dessa forma, as vozes das mulheres manifestadas na sessão solene não se equilibram na figura do assassino de Realengo; a ele, não há qualquer menção, direta ou indireta. A escola pública emerge como protagonista nos pronunciamentos delas. Isso me faz recordar algo dito a mim por uma pesquisadora e docente da área da psicologia escolar, com quem conversei durante a pesquisa de campo de meu doutoramento ${ }^{8}$. Ela contou-me que costuma discutir o caso de Realengo com seus estudantes quando o assunto em sala de aula é o bullying:

Sempre faço a seguinte reflexão: o criminoso foi um rapaz que disseram ter sofrido violência na escola. Mas ele não foi atrás dos agressores, porque ele poderia ter ido; ele foi atrás da escola. O acerto de contas é com a escola, não é com os agressores. (...) Então, tem algo aí pra gente refletir (...). Por que o acerto de contas é com a escola? Por que se picha muro de escola, por que se destrói escola? Eu acho que tem algo aí que está sendo comunicado.

A fala de Adriana, na posição de presidente da Associação Anjos de Realengo, elabora constatações, faz perguntas e buscas respostas nessa mesma direção. Dessa maneira, minha interpretação etnográfica é que, ao agenciar a noção de bullying, Adriana o faz inserindo-a num "paradigma sociológico", no âmbito de um "problema estrutural” (Derber; Magrass, 2016), em que a violência está longe de ser, nas palavras dela, uma "fatalidade". Logo, trata-se de um agenciamento enormemente diferenciado daquele verificado no polo discursivo estatal, a despeito do emprego do mesmo termo significante.

Adriana expõe com claridade a concentração na escola pública brasileira daquilo que Giorgio Agamben ( 2007) classifica por "vida nua": aquela não revestida de valor político, portanto, passível de exterminação, capaz de se dar de forma imediata ou não. Como bem precisa Michel Foucault (2002), a potencialização dos riscos de morte, a exposição à morte, o desprezo, o banimento e a "morte política" configuram também meios indiretos eficientes de tirar a vida, posto ameaçarem sua plenitude. Isso apareceu com nitidez no depoimento lúcido ofertado a mim por uma educadora da rede pública de ensino gaúcha, também durante meu trabalho de campo ${ }^{9}$. Ao avaliar seus desafios institucionais perante um aluno de aprendizado descompassado, disse-me ela:

\footnotetext{
${ }^{8}$ Entrevista de maio de 2015.

${ }^{9}$ Entrevista de novembro de 2015.
} 
Porque ele tinha um tempo diferente, eu o acusei. Será que não fazemos isso sempre? Agora eu consigo ver isso. Quantos será eu já matei, em termos de educação, porque não respeitava a diferença? Agora, eu quero salvar. Mas eu poderia ter matado aquele aluno se não tivesse me dado conta da minha postura (grifos meus).

O dilema dessa professora, ao exercer sua profissão num ambiente tangenciado pela opressão e pela precariedade nas mais diversas direções, vai de encontro ao clamor do testemunho de Adriana, por uma escola pública onde todos os estudantes tenham a chance de se construírem de forma segura enquanto sujeitos. Logo, é uma seguridade que não reside stricto sensu no policiamento escolar ou na instalação de detectores de metais.

De um lado, a fala de Adriana - a exemplo daquela da advogada Cristina Leonardo - evoca duas "representações coletivas" que, segundo Simoni L. Guedes (2014), manifestam-se paradoxalmente em meio à sociedade brasileira: uma "valorização difusa da educação" como solução por excelência para o enfrentamento da violência urbana e, de modo concomitante, uma igualmente "difusa desvalorização da escola pública" como ferramenta para tal transformação. De outro lado, porém, entendo que leitura sociopolítica de Adriana consegue avançar para além dessas percepções. A ativista não se concentra em demandas específicas, como a universalização do ensino, o aperfeiçoamento do conteúdo programático ou o melhoramento infraestrutural dos espaços educacionais, mas, ao mesmo tempo, toca em todos esses tópicos desde uma ótica holista.

À luz das reflexões de Guacira L. Louro (2000), advoga-se aqui que o discurso de Adriana fala da conformação de uma escola onde "identidades sociais" possam se desenvolver e habitar com completude de sentido e de ação. Atentar para os modos como se dá esse processo de socialização é algo vital nas sociedades urbanas ocidentais pois, como enfatiza a autora, essas coletividades “... apostam muito na escola, criando mecanismos legais e morais para obrigar que todos enviem seus filhos e filhas à instituição e que esses ali permaneçam alguns anos" (ibid.: 13). Ou seja, como assinala Erving Goffman (1975), o ingresso na escola constitui um momento da vida em que esses sujeitos ultrapassam os limites da convivência doméstica, em geral restrita a um grupo determinado, para entrar em contato com a multidão, a alteridade e as relações de poder entretecidas nesses domínios, no interior de um processo de rebatimento inevitável sobre as configurações identitárias. 
Portanto, na linha do ressaltado por Marcos Rolim (2014), o testemunho de Adriana não abraça uma "teoria da educação como resposta para todos os problemas". Trata-se, sim, de um depoimento que reconhece o "fracasso sistêmico" da rede de ensino público brasileira, isto é, seu quinhão numa "socialização maléfica" que espalha uma "pré-cidadania" e, por conseguinte, interdita a crianças e jovens possibilidades de reconhecimento, respeito e agência na sociedade. Na contramão disso, ainda sob a lógica desse mesmo autor, aparece no discurso de Adriana o desejo por uma vivência escolar que, em vez de variável de risco, atue como "fator protetivo" contra a materialização tanto de agentes, como de vítimas de violência.

Em seu pronunciamento, a ativista dirige essa aspiração diretamente ao deputado presidente da sessão solene, entendido como representante de um corpo de parlamentares com responsabilidade sobre tal quadro. Adriana, portanto, personaliza o ator político, ao contrário do que ocorre no discurso do deputado, no qual os agentes públicos surgem de maneira genérica e ele mesmo parece descolado de sua própria classe.

Logo, enquanto o deputado posiciona o episódio de Realengo como uma excepcionalidade e propõe remediações pontuais - como a criação de um Dia Estadual de Combate ao Bullying ou a instalação de detectores de metais nas escolas -, Adriana “descende ao ordinário" (Das, 2007). Meu argumento é que ela projeta a ideia de bullying para denunciar "processos cruéis de produção de vidas dispensáveis" (Vianna; Farias, 2011) em curso dentro das escolas brasileiras. Dessa maneira, tomando de empréstimo as palavras dessas autoras, pode-se dizer que a ativista se movimenta no "... duplo limite político da perda pessoal e da ação coletiva, dos vivos e dos mortos, da contenção e do desvario, do cotidiano e do extraordinário" (ibid.: 112).

\section{Uma agenda transnacional}

Em 2016, a Organização das Nações Unidas (ONU) trouxe a público o relatório "Terminando o tormento: enfrentando o bullying do pátio da escola ao ciberespaço"10. Esse documento - cujo escopo é a Agenda 2030 para o Desenvolvimento Sustentável e, dentro dela, o objetivo de terminar com todas as formas de violência contra crianças -

\footnotetext{
${ }^{10}$ No original, "Ending the torment: tackling bullying from the schoolyard to cyberspace".
} 
foi o primeiro do organismo supranacional unicamente focado no bullying (United Nations, 2016).

Uma referência inicial da ONU à temática aparece uma década antes, porém, num estudo de natureza mais ampla, intitulado "World Report on Violence Against Children" (Pinheiro, 2006) ${ }^{11}$. O assunto ainda viria à tona de forma pontual em 2009, num guia dirigido a professores, chamado "Stopping Violence in Schools", elaborado no âmbito da Década Internacional pela Cultura da Paz e Não Violência para com as Crianças do Mundo (2001-2010) ${ }^{12}$. Nesse guia, ao contrário do world report antes mencionado, o bullying recebe uma definição estabelecida, como um processo de intimidação sistemática entre pares no ambiente escolar, com possibilidade de conduzir a "ataques físicos fatais" (Unesco, 2009).

Essa íntima relação com "eventos críticos” (Das, 2007) reaparece e se mostra fundante à argumentação apresentada pelo relatório pioneiro a tratar do bullying com exclusividade, o qual conta com a assinatura de cientistas, ativistas e ainda consultores das agências das Nações Unidas (United Nations, 2016). Dentre os autores, está o sueco Dan Olweus, reconhecido como o precursor das pesquisas científicas sobre bullying; Susan Limber, investigadora responsável pela difusão dos estudos de Olweus nos Estados Unidos; como também Christina Salmivalli, idealizadora do KiVa Program, renomado programa antibullying escolar sediado na Finlândia, já citado aqui.

Tal time de experts referenda um conjunto de elementos a compor uma narrativa contemporânea sobre o bullying. Em meio a esses componentes, aparece calcificada a percepção de que o bullying, enquanto fenômeno de violência, pode atuar como gatilho tanto para suicídios, quanto para ataques armados juvenis. Acerca destes últimos, o relatório respalda-se por dados de uma investigação do governo norte-americano, motivada pelo impacto do episódio de Columbine High School (United States Secret Services; United States Department of Education, 2004). Segundo essa pesquisa, os Estados Unidos registraram, no período de 1974 a 2000, 34 tiroteios em escolas, nos quais $75 \%$ dos 41 perpetradores teriam sido alvos de intimidações, perseguições e/ou ferimentos previamente aos atos de violência extrema.

\footnotetext{
${ }^{11}$ Em livre tradução, "Relatório Mundial sobre Violência contra Crianças".

${ }^{12}$ Em livre tradução, "Parar a violência nas escolas". Esse material pedagógico foi também comemorativo do vigésimo aniversário da Convenção sobre os Direitos da Criança, formalizada em 1989 e ratificada por todos os países-membros das Nações Unidas com exceção dos Estados Unidos. Dentre as razões para a não aprovação formal do governo norte-americano, desponta a tensão gerada pelo artigo da convenção que veta a pena de morte e a prisão perpétua para menores de 18 anos e, dessa maneira, conflita com legislações estaduais em vigor no país (Rosemberg; Mariano, 2010).
} 
Além do vínculo com eventos letais, o relatório da ONU (op. cit.) postula que o bullying pode alavancar - seja em vítimas, seja em agressores - desordens físicas (como dores de cabeça e de estômago, perda de apetite e fadiga), emocionais (como baixa autoestima, ansiedade e depressão) e também pedagógicas, comprometedoras da performance escolar. Ademais, as cicatrizes deixadas pelos distúrbios seriam capazes de conduzir os sujeitos na idade adulta a comportamentos de risco e antissociais, dentre eles, a drogadição e a delinquência. Em tal panorama, certos grupos sociais teriam mais susceptibilidade aos males: crianças e jovens com deficiência ou dificuldade de aprendizado; pertencentes a grupos étnico-raciais, linguísticos ou religiosos "minoritários"; de orientação sexual ou gênero não conformativos; de aparência estética não afinada a padrões dominantes; como também na condição de refugiados.

Por conseguinte, o documento destaca que a prática do bullying, como de qualquer violência “... enfraquece o progresso social, gera altos custos para a sociedade, retarda o desenvolvimento econômico e erode o capital humano e social das nações" (ibid.: VII). Como trilha de enfrentamento do fenômeno, o relatório recomenda que

\footnotetext{
... por meio do aprimoramento do senso de responsabilidade das crianças em prevenir a discriminação e a violência, ao promover a solidariedade, o respeito mútuo e a tolerância, os adultos podem ajudar a construir um ambiente inclusivo onde nenhuma criança é deixada para trás e onde as crianças recebem suporte para conquistar habilidades para a vida, aprendendo a lidar com a adversidade, bem como fortalecendo sua resiliência e autoconfiança" (ibid.: VI) ${ }^{13}$.
}

Com tal argumentação, portanto, as Nações Unidas catapultam nesse relatório as arestas de um debate transnacional sobre bullying, que compartilha do tom dos estudos desenvolvidos nos principais polos de pesquisa, situados ao Norte do mundo. A etnografia desse gênero de documento revela-se importante para desconstruir seu status ocidental de "fonte de proteção de valores ontológicos" (Schuch, 2005), de modo a vêlo como o que realmente é: um material de estatuto particular, fruto de uma filosofia política específica, situado num tempo/espaço singular. Com base numa analítica desse tipo, é possível trazer para o primeiro plano a atuação dos "empreendedores morais" (Becker, 2008), responsáveis por moldar a noção de bullying, tanto em textos, como em práticas.

\footnotetext{
${ }^{13}$ Ambas as traduções do parágrafo são minhas.
} 
Percebe-se ecoar no referido relatório das Nações Unidas uma contraste pulsante no debate contemporâneo sobre a realidade infanto-juvenil no Ocidente: aquele entre "crianças em risco" e "crianças como risco" (Stephens, 1995). Dito de outro modo, verifica-se nessa discussão um consenso de que é preciso lidar com crianças "fora de lugar" não apenas na posição de vítimas, mas também de agentes de violência. Fortalece-se, em tal contextura, uma busca obstinada em promover uma infância "normal" que, como discute Clarice Cohn (2013), seria determinante para a conduta civilizada do indivíduo jovem e, depois, adulto. Sob essa ótica, a vivência na primeira fase da vida de situações anômalas - como o bullying - conduziria a males físicos e psíquicos, quando não ao suicídio e à criminalidade.

Todavia, nos tratados sobre infância das Nações Unidas, a normalidade não surge cercada de especificação, tendo em vista tomar a forma de um princípio ético dado e universal. Nas entrelinhas, quem seria, então, a criança "normal"? Sob a perspectiva desses documentos, subsidiados prioritariamente pelos saberes das ciências médicas e psicológicas, tal modelo encontra materialidade no infante ocidental, entendido como indivíduo protegido por uma família nuclear tradicional, na qual é amado, ouvido e compreendido e desde onde está garantido seu acesso à saúde, à educação e à cultura (Stephens, 1995). Ademais, como fica claro no relatório centrado no bullying, trata-se do sujeito educado para a tolerância, a responsabilidade, a autoconfiança e a resiliência (United Nations, 2016).

Vê-se em jogo aí uma moldura de infância que informa mais sobre as aspirações dos adultos do que sobre as crianças em sua concretude. Trata-se de uma percepção de cidadania oriunda de um modo de governo presente nas mais poderosas democracias neoliberais, para as quais as Nações Unidas, historicamente, têm atuado enquanto organismo mediador na difusão de valores, saberes e técnicas, do Norte para o Sul do mundo (Stephens, op. cit.). São sociedades onde impera um capitalismo avançado de "estilo emocional" (Illouz, 2007), ontologicamente assentado no arranjo das subjetividades que, uma vez alvo de intervenções psicoterapêuticas, se tornariam ajustadas à resolução de problemas interpessoais e conflitos coletivos, em direção à pacificação social. 
Em tal cenário, de um lado, as crianças recebem direitos; de outro, porém, são cada vez mais despolitizadas enquanto sujeitos. Primeiramente, porque não há como estabelecer uma normalidade e, portanto, universalidade para a infância. Em uma revisão do estado da arte da antropologia da criança, Clarice Cohn (2013) demonstra, a partir da exploração de uma série de etnografias, que coletividades diferentes vivenciam essa etapa do desenvolvimento humano de formas variadas. Isso significa que nem sempre rendem a esse período um atributo de singularidade como ocorre no Ocidente, sendo assim a infância apenas mais uma das fases de vida dos sujeitos.

Além disso, as crianças são posicionadas nesses documentos supranacionais em uma "duty-free society" (Scheper-Hughes; Sargent,1998), ou seja, numa sociedade liberta de obrigações, onde os próprios infantes, pelo aprendizado socioemocional propagado pelos adultos, devem se constituir enquanto sujeitos responsáveis pelo combate da violência no mundo. Portanto, ainda que a vulnerabilidade de certos grupos sociais seja enfatizada, como ocorre no relatório da ONU centrado no bullying, vê-se suspendida de abordagem a precarização das estruturas estatais de bem-estar, as relações de dominação Norte-Sul e o aprofundamento avassalador de desigualdades em diferentes frentes. Diante de todo esse panorama de avanço neoliberal, que tem se mostrado deveras hostil à vida das crianças, soa no mínimo descabido sugerir o empoderamento delas mesmas para resolver algo que as ultrapassa e oprime.

Logo, verifica-se nesse quadro de debate transnacional um fluxo Norte-Sul em prol da estabilização de um campo semântico específico a gravitar em torno do bullying e, por consequência, dos episódios de violência extrema a ele associados. Entretanto, a imersão etnográfica nos contextos onde "eventos críticos" (Das, 2007) tomam forma - o que foi feito aqui em relação ao ataque armado à Escola Tasso da Silveira no Rio de Janeiro - evidencia que, embora pujante, essa corrente pela solidificação de significado não flui sem obstáculos, conformados pela atuação local de atores como a Associação Anjos de Realengo.

No ativismo dos membros dessa entidade, construído nos meandros da dor e do cotidiano, ainda que tenha mantida sua feição de dispositivo de governo, o construto do bullying surge também agenciado, nas palavras de Michel Foucault (1993), como uma "tecnologia do eu". Nessa forma, tal conceito passa a compor o repertório de ação de indivíduos que, confrontados pelo "conhecimento venenoso" (Das, op. cit.) do 
sofrimento gerado pelo trágico, redesenham subjetividades, trajetórias e projetos para seguir vivendo.

A etnografia dessa sinuosa e árdua reocupação de um mundo despedaçado é ímpar na tarefa de politizar o debate sobre violência num âmbito especificamente nacional, na contramão de generalizações oriundas de uma esfera internacional. Desde essa perspectiva politizada, falar de bullying não pressupõe apenas considerar subjetivamente cada criança ou as relações das crianças entre si, mas implica, necessariamente, tratar sobre o papel de um espaço de sociabilidade primordial a elas: a escola brasileira, com seus extensos malogros e, também, com suas possibilidades de transformação.

\section{Referências}

AGAMBEN, Giorgio. Homo sacer: o poder soberano e a vida nua. Belo Horizonte: Editora da UFMG, 2007.

ANPED - ASSOCIAÇÃO NACIONAL DE PÓS-GRADUAÇÃO E PESQUISA EM EDUCAÇÃO. Carta aberta sobre avaliação em larga escala de habilidades não cognitivas de crianças e jovens. Disponível em: <www.anped.org.br>. 07 nov. 2014.

ANPED - ASSOCIAÇÃO NACIONAL DE PÓS-GRADUAÇÃO E PESQUISA EM EDUCAÇÃO. Carta de entidades da Educação em resposta a declarações de Viviane Senna em entrevista à Folha de São Paulo. Disponível em: 〈www.anped.org.br〉. 26 jun. 2015.

APA - AMERICAN PSYCHOLOGICAL ASSOCIATION. Are Zero Tolerance Policies effective in the schools? An evidentiary review and recommendations. American Psychologist, v. 63, n. 9, p. 852-862, Dec. 2008.

BECKER, Howard S. Outsiders: estudo de sociologia do desvio. Rio de Janeiro: Zahar, 2008.

BEZERRA, Benilton. Há fatos que resistem a explicações simples. Instituto Humanitas Unisinos, 08 maio 2011. Disponível em: <www.ihu.unisinos.br〉.

BORGES, Helena. Os sobreviventes do massacre de Realengo. Isto é, 27 mar. 2015. Disponível em: <http://istoe.com.br>.

CARDOSO DE OLIVEIRA, Roberto. Antropologia e moralidade. Revista Brasileira de Ciências Sociais, São Paulo, v. 24, p. 110-121, fev. 1994.

CASEL - COLLABORATIVE FOR ACADEMIC, SOCIAL, AND EMOTIONAL LEARNING. Social and emotional learning and bullying prevention. s/d. Disponível em: <www.casel.org/bullying/>. Acesso em: 01 fev. 2016.

CHUNG, Jen. Cuomo: Subway Therapy post-it notes will be preserved. Gothamist, 16 Dec. 2016. Disponível em: <http://gothamist.com>.

COHN, Clarice. Concepções de infância e infâncias: um estado da arte da antropologia da criança no Brasil. Civitas, Porto Alegre, v. 13, n. 2, p. 221-244, maio/ago. 2013.

COLLINS, John F. Revolt of the saints: memory and redemption in the twilight of Brazilian racial democracy. Durham and London: Duke University Press, 2015.

CORNELL, Dewey; LIMBER, Susan P. Law and policy on the concept of bullying at school. American Psychologist, v. 70, n. 4, p. 333-343, jun. 2015.

COSTELLO, Maureen B. The Trump Effect: the impact of the presidential campaign on our nation's schools. Montgomery: Southern Poverty Law Center, 2016.

DAS, Veena. Life and words: violence and the descent into the ordinary. Berkeley, Los Angeles: University of California Press, 2007. 
DERBER, Charles; MAGRASS, Yale R. Bully Nation: how the American establishment creates a bullying society. Kansas: University Press of Kansas, 2016.

ELIAS, Norbert. Os alemães: a luta pelo poder e a evolução do habitus nos séculos XIX e XX. Rio de Janeiro: Zahar, 1997.

ESTÚDIO I. Cinco anos após o massacre de Realengo, mãe lança livro infantil em homenagem à filha. Globo News, 12 dez. 2016. Disponível em: 〈http://g1.globo.com>.

FASSIN, Didier; RECHTMAN, Richard. The empire of trauma: an inquiry into the condition of victimhood. Princeton, Oxford: Princeton University Press, 2009.

FLANNERY, Daniel J. et al. Bullying prevention: a summary of the Report of the National Academies of Sciences, Engineering, and Medicine. Prevention Science, v. 17, n. 8, p. 10441053, nov. 2016.

FOUCAULT, Michel. Introdução. In: História da sexualidade 2: o uso dos prazeres. Rio de Janeiro: Graal, 1984. p. 07-32.

FOUCAULT, Michel. Verdade e subjectividade. Revista de Comunicação e Linguagem, Lisboa, v. 19, p. 203-223, 1993.

FOUCAULT, Michel. Aula de 17 de março de 1976. In: Em defesa da sociedade. Curso no Collège de France. São Paulo: Martins Fontes, 2002. p. 285-315.

GOFFMAN, Erving. Estigma: notas sobre a manipulação da identidade deteriorada. Rio de Janeiro: Zahar, 1975.

GOULD, Deborah. On affect and protest. In: STAIGER, J.; CVETKOVICH, A.; REYNOLDS, A. (ed.). Political emotions: new agendas in communication. New York, London: Routledge, 2010. p. 18-44.

GUEDES, Simoni L. Por uma abordagem etnográfica dos contextos pedagógicos. In: GUEDES, S. L.; CIPINIUK, T. A. (org.) Abordagens etnográficas sobre educação: adentrando os muros das escolas. Niterói: Alternativa, 2014. p. 7-10.

HACKING, Ian. Construindo tipos: o caso de abusos contra crianças. Cadernos Pagu, v. 40, p. 7-66, jun. 2013.

HANNERZ, Ulf. Being there... and there... and there! Reflections on multi-sited ethnography. Ethnography, v. 4, n. 2, p. 201-216, 2003.

HIRSCH, Lee. Bully. Estados Unidos, 2011. Documentário, 99 min.

HOLANDA, Sérgio B. O homem cordial. In: Raízes do Brasil. 26. ed. São Paulo: Companhia das Letras, 1995. p. 139-151.

ILLOUZ, Eva. Cold intimacies: the making of emotional capitalism. Cambridge: Polity Press, 2007.

JORNAL DA GLOBO. Atirador de Realengo grava vídeo e conta supostos motivos do crime. Globo, 12 abr. 2011. Disponível em: 〈www.youtube.com/watch?v=_Oi14J4920I〉.

KARNAL, Leandro. O ódio no Brasil. Café Filosófico CPFL. TV Cultura, 2011. Disponível em: <www.cpflcultura.com.br>.

KLEBOLD, Sue. A Mother's reckoning: living in the aftermath of tragedy. New York: Crown Publishers, 2016.

LOURO, Guacira L. Pedagogias da sexualidade. In: LOURO, G. L. et al. O corpo educado: pedagogias da sexualidade. 2. ed. Belo Horizonte: Autêntica, 2000. p. 7-34.

MISSE, Michel A violência como sujeito difuso. In: FEGHALI, J.; MENDES, C.; LEMGRUBER, J. (org.). Reflexões sobre a violência urbana: (in)segurança e (des)esperanças. Rio de Janeiro: Mauad X, 2006. p. 19-31.

MOORE, Michael. Tiros em Columbine. Estados Unidos; Canadá, 2002. Documentário, 120 $\min$.

OLWEUS, Dan. Bullying at school. Malden, MA: Blackwell Publishing, 2006.

OLWEUS, Dan. School bullying: development and some important challenges. Annual Review of Clinical Psychology, v. 9, p. 751-780, 2013.

OLWEUS, Dan; LIMBER, Susan P. Bullying in school: evaluation and dissemination of the Olweus Bullying Prevention Program. American Journal of Orthopsychiatry, v. 80, n. 1, p. 124$134,2010$. 
ORTNER, Sherry. Poder e projetos: reflexões sobre a agência. In: GROSSI, M. P.; ECKERT, C.; FRY, P. (org.). Conferências e diálogos: saberes e práticas antropológicas. Blumenau: Nova Letra, 2007. p. 45-80.

PINHEIRO, Paulo S. World report on violence against children. Geneva: United Nations, 2006. PIZA, Paulo T. Porteiro de colégio tradicional de SP escreve livro em cordel sobre bullying. G1, São Paulo, 30 abr. 2017. Disponível em: 〈http://g1.globo.com>.

PORTER, Susan E. Bully Nation: why America's approach to childhood aggression is bad for everyone. St. Paul: Paragon House, 2013.

R7. Atirador Wellington Menezes de Oliveira [diz] que bullying motivou massacre. 19 abr. 2011. Disponível em: <https://www.youtube.com/watch?v=fdGyjC9TFHI>.

RITTO, Cecília. A construção de um monstro: na infância, humilhações e solidão; na juventude, jogos de tiro no computador. Veja.com, 08 abr. 2011. Disponível em: 〈http://veja.abril.com.br〉.

ROLIM, Marcos. A formação de jovens violentos: para uma etiologia da disposicionalidade violenta. 247f. Tese (Doutorado em Sociologia) - Universidade Federal do Rio Grande do Sul, Porto Alegre, 2014.

ROSE, Nikolas. The biology of control. In: The politics of life itself: biomedicine, power, and subjectivity in the twenty first century. Princeton: Princeton University Press, 2007. p. 224-251.

ROSEMBERG, Fúlvia; MARIANO, Carmem L. S. A Convenção Internacional sobre os Direitos da Criança: debates e tensões. Cadernos de Pesquisa, v. 40, n. 141, p. 693-728, set./dez. 2010.

SANTOS, Daniel; PRIMI, Ricardo. Desenvolvimento socioemocional e aprendizado escolar: uma proposta de mensuração para apoiar políticas públicas. Resultados preliminares do projeto de medição de competências socioemocionais no Rio de Janeiro. São Paulo: OCDE; Instituto Ayrton Senna; Secretaria de Educação do Governo do Rio de Janeiro, 2014.

SCHEPER-HUGHES, Nancy; SARGENT, Carolyn (ed.). Introduction. In: Small wars: the cultural politics of childhood. Berkeley, Los Angeles: University of California Press, 1998. p. 133.

SCHUCH, Patrice. Práticas de justiça: uma etnografia do "campo de atenção ao adolescente infrator" no Rio Grande do Sul, depois do Estatuto da Criança e do Adolescente. 345f. Tese (Doutorado em Antropologia Social) - Universidade Federal do Rio Grande do Sul, Porto Alegre, 2005.

SMITH, Peter K.; KWAK, Keumjoo; TODA, Yuichi (ed.). Reflections on bullying in Eastern and Western perspectives. In: School bullying in different cultures: Eastern and Western perspectives. Cambridge: University Printing House, 2016. p. 399-419.

STEPHENS, Sharon (ed.). Introduction: children and the politics of culture in "late capitalism". In: Children and the politics of culture. Princeton: Princeton University Press, 1995. p. 3-48.

STRATHERN, Marilyn. A relação: acerca da complexidade e da escala. In: O efeito etnográfico e outros ensaios. São Paulo: Cosac Naify, 2014. p. 263-294.

THE WEEK. Melania Trump's anti-bullying speech raised an obvious question, and Anderson Cooper asked it. 04 nov. 2016. Disponível em: 〈http://theweek.com>.

UNESCO - UNITED NATIONS EDUCATIONAL, SCIENTIFIC AND CULTURAL ORGANIZATION. Stopping violence in schools: a guide for teachers. Paris: Section for the Promotion of Rights and Values in Education, 2009.

UNITED NATIONS. Ending the torment: tackling bullying from the schoolyard to cyberspace. New York: Office of the Special Representative of the Secretary-General on Violence against Children, 2016.

UNITED STATES SECRET SERVICES; UNITED STATES DEPARTMENT OF EDUCATION. The final report and findings of safe school initiative: implications for the prevention of school attacks in the United States. Washington, D.C, 2004.

VIANNA, Adriana; FARIAS, Juliana. A guerra das mães: dor e política em situações de violência institucional. Cadernos Pagu, v. 37, p. 79-116, jul. 2011.

VIGARELLO, Georges. História do estupro: violência sexual nos séculos XVI-XX. Rio de Janeiro: Zahar, 1998. 
WACQUANT, Loïc. Punir os pobres: a nova gestão da miséria nos Estados Unidos. [A onda punitiva]. 3 ed. Rio de Janeiro: Revan, 2007.

Recebido em: 23/05/2017. Aprovado em: 28/06/2017. 